\title{
Separation of Judiciary and Judicial Independence in Bangladesh: An Appraisal
}

\author{
Mohammad Abdul Hannan1, Md. Arifuzzaman² \\ ${ }^{1}$ Department of Law, University of Rajshahi, Rajshahi, Bangladesh \\ ${ }^{2}$ Department of Law, Green University of Bangladesh, Dhaka, Bangladesh \\ Email: mahannan.law@ru.ac.bd, arif@law.green.edu.bd
}

How to cite this paper: Hannan, M.A. and Arifuzzaman, Md. (2021) Separation of Judiciary and Judicial Independence in Bangladesh: An Appraisal. Open Access Library Journal, 8: e7002. https://doi.org/10.4236/oalib.1107002

Received: November 16, 2020

Accepted: April 27, 2021

Published: April 30, 2021

Copyright $\odot 2021$ by author(s) and Open Access Library Inc.

This work is licensed under the Creative Commons Attribution International License (CC BY 4.0).

http://creativecommons.org/licenses/by/4.0/

(c) (i) Open Access

\begin{abstract}
Judiciary is not only confined to be an organ like executive and legislature but also something more. It is the last hope and aspiration to restore the rights of citizen in a country. But this judiciary cannot act to restore these rights unless and until it is free from any undue influence and interference of any other organ. Therefore, it is an obvious need that the judiciary should be separated in the true sense to perform its functions independently which is the main object of the judiciary. And where there is no effective separation of judiciary, there is no independent judiciary and where there is no independent judiciary, there is no rule of law. But mere separation is not enough to perform its function effectively. This paper will analyze the terms separation of judiciary and judicial independence and evaluate their proper implementation in Bangladesh and also some other factors which are essential with the separation of the judiciary to ensure independence. In Bangladesh, Judiciary has been separated from the executive in 2007. But due to some theoretical problems in justice system, the practice of executive interferences over judiciary is still continuing in Bangladesh in some context. "Judicial independence" is the concept that the judiciary needs to be kept away from the other branches of government. And the "separation of judiciary" is the pre-condition to judicial independence. To make concept of the research clear at first some terms should be made clear. Judicial independence refers to the separation of judiciary and independence of judiciary. Separation of the judiciary from the executive is established by the constitution of Bangladesh from its origin. But it was limited to mere documentary recognition before the decision of Masdar Hossain case in 2007 through which the separation of judiciary as well judicial independence was established in true sense. But it is not clear whether the judicial independence is actually implicated in proper way. To establish the proper judicial system, the separation of judiciary is a vital issue.
\end{abstract}




\section{Subject Areas}

Law

\section{Keywords}

Separation, Judiciary, Executive, Judicial Independence, Appraisal

\section{Introduction}

The first thing which must come into consideration of the administration of justice in a society is the independence of judiciary. Independent judiciary is the sin qua non of a democratic government. Among the three organs of a democratic state, judiciary has the duty to decide upon the application of the existing law in individual cases. A social structure remains sound and organized with the aid of a sound judicial system. An independent, impartial and informed judiciary holds a central place in the apprehension of just, honest, open and accountable government. A judiciary must be independent from the executive if it is to perform its constitutional role of reviewing legal actions.

Judiciary is not only confined to be an organ like executive and legislature but also something more. It is the last hope and aspiration to restore the rights of citizen in a country. But this judiciary cannot act to restore these rights unless and until it is free from any undue influence and interference of any other organ. Therefore, it is an obvious need that the judiciary should be separated in true sense to perform its functions independently which is the main object of the judiciary. And where there is no effective separation of judiciary, there is no independent judiciary and where there is no independent judiciary, there is no rule of law. But mere separation is not enough to perform its function effectively. This paper will analyze the terms separation of judiciary and judicial independence and evaluate their proper implementation in Bangladesh and also some other factors which are essential with the separation of the judiciary to ensure independence.

In Bangladesh, judiciary has been separated from the executive in 2007. But due to some theoretical problems in justice system, the practice of executive interferences over judiciary is still continuing in Bangladesh in some context.

"Judicial independence" is the concept that the judiciary needs to be kept away from the other branches of government. And the "separation of judiciary" is the pre-condition to judicial independence. To make concept of the research clear at first some terms should be made clear.

Judicial independence refers to the separation of judiciary and independence of judiciary. So first of all which term comes forward is the "Judiciary". "Judiciary" means the courts of law and judges in a country, the branch of government that includes courts of law and judges in which judicial power is vested.

Now, "Independence of Judiciary" refers to a court system free from any in- 
fluence and interference of other organs of the state. So the independence of the judiciary can be understood as the independence of the institution of the judiciary and also the independence of the judges which form a part of the judiciary. Judicial Independence is vital and important to the idea of Reparation of powers. The term "Separation of Powers" means the balanced division of the administrative power of the three organs of the state namely the legislative, the executive and the judiciary. From this overview, particularly Separation of Judiciary from Executive means a situation in which the judiciary acts as an organ of its own body free from improper influence of executive.

Separation of the judiciary from the executive is established by the constitution of Bangladesh from its origin [1]. But it was limited to mere documentary recognition before the decision of Masdar Hossain case [2] in 2007 through which the separation of judiciary as well judicial independence was established in true sense. But it is not clear whether the judicial independence is actually implicated in proper way. To establish the proper judicial system the separation of judiciary is a vital issue.

Bangladesh Judicial systems are often compared to that of other developed countries in few instants. But most of the time she is abused due to existing administrative corruption prevalent in all departments of the states. To remove this problem one of the most effective ways is, to confirm the balanced power of the organs. This paper has sought to focus on this point. The objectives of the paper are to analyze the term "separation of judiciary" and "judicial independence" and to seek the present scenario of the implication of the terms. It also aims to find out the barriers and give a recommending perception.

The field of study is specific because it covers only the Bangladesh perspective of the evaluation of Implication of the judicial independence. All the major issues regarding the concept, background, statutory value, implication, present scenario and also some measures to ensure judicial independence have been discussed within this article. The main focus is on the situation how far it is implemented in Bangladesh. The problems and drawbacks behinds the situation which hinders the independence of judiciary have also been identified through the Article. Specific measures that should have been taken to resolve those problems are also the subject matter of the Article.

The whole article has been conducted on the basis a theoretical discussion by qualitative method. This research has been made on the basis of studying important books, case laws, journals published by different institutions, using legal dictionary, available research works, visiting several websites and newspaper analysis. The portion that has been quoted from these sources has been mentioned in the Article.

\section{Separation of Judiciary in Bangladesh}

During the British colonial there was a demand for the separation of the judiciary from the executive. Many steps also have been taken by the governing au- 
thority of the state from that ancient period to the new era of independent Bangladesh to make the demand fulfilled. As well as Article 22 of the Constitution of the Republic of Bangladesh meets the demand. But it also took a long time to implement this article. In accordance with the guidelines given by the Appellate Division of the Bangladesh Supreme Court in Masdar Hossain case [2] the article was implementing by separation of judiciary from the executive. Now, this Article presents the way of journey towards separation of judiciary and also the present scenario of the goal "judicial independence" in Bangladesh.

\subsection{Separation of the Judiciary in the Constitution}

The judicial independence of all judicial officers is unconditional according to the Constitution of Bangladesh [3]. This ideal is protected primarily through the concept of separation of the judiciary from the other organs of government. Article 22 of the Constitution states directly and unquestionably, "The state shall ensure the separation of the judiciary from the executive organs of the State." Article 95(1) of the Constitution addressed the method of appointment for the Supreme Court, "the President shall appoint the Chief Justice and other Judges." But Article 113 empowers the Chief Justice to appoint the staff of the Supreme Court, to determine the conditions of service of the staff, and to make rules relating appointment of the staff are subject to previous approval and clearance. These restrictions on the power of appointment of its staff are results of the administrative freedom of the Supreme Court.

Article 115 and 116 of the Constitution states that appointment of persons to offices in the judicial service or of magistrates exercising judicial functions, shall be made by the President. Though the control including the power of posting, promotion and grant of leave and discipline of persons employed in the judicial service and magistrates exercising judicial functions shall vest in the President, but it shall be exercised by him in consultation with the Supreme Court. Though the Constitution is the safeguard of the separation of judiciary, through some of the above mentioned provisions, the executive branch practices to influence the functions the judiciary in Bangladesh So, what the constitution has been done can be described as a distribution of the powers of the republic to the three organs of the government and it provides for separation of powers in the sense that no organ can transgress the limit set by the constitution [4].

\subsection{Steps to Separation of Judiciary}

As regards independence and separation of judiciary, the Constitution of 1972 is fairly developed. Art 22 states that "the state shall ensure the separation of the judiciary from the executive organs of the state" as one of the fundamental principles of state policy. It is not readily judicially enforceable. But the Fourth Amendment undermined the constitutionalism itself, which obviously destroyed the independence of judiciary. In 1976 an initiative was taken to separate the judiciary from executive. A Law Committee headed by Justice Kemaluddin Hos- 
sain recommended that subordinate judiciary on the criminal side should be separated from the executive in some stages [5]. In 1987, second initiative was taken to separate the magistracy by a Bill for amending Code of Criminal Procedure, In 1991, a private member's bill was introduced for further amendment the Articles 95, 98, 115 and 116 of the Constitution, for ensuring separation of the subordinate judiciary from the executive branch. The Bill was sent to a select Committee, which had carried out about 13 meetings to consider the proposal. However, no further steps were taken to pass the Bill. Next attempt was taken regarding separation of judiciary from the executive in 1995 when the renowned Masdar Hossain case was filed. The landmark decision of Masdar Hossain case [2] was determined on the issue that to what extent the Constitution of the Republic of Bangladesh has actually ensured the separation of judiciary from the executive organs of the State.

\subsection{Masdar Hossain Case and Separation of Judiciary}

Masdar Hossain along with 441 judicial officers who were judges in different civil courts filed a Writ Petition No. 2424. Ultimately, hearing of the case was held on 1 April 1997. After a long hiring with valuable comments arid citations by Dr. Kamal Hossain, Syed Istiaq Ahmed and Mr. Amir-Ul Islam, the court delivered its historic judgment on 7 May 1997. Then the government favored an appeal to the Appellate Division but the Appellate Division partly reversed the decision of the High Court Division and gave its landmark decision with 12 points directives on 2 December 1999. The Appellate Division directed the Government to implement these 12 points directives including formation of separate JSC and Judicial Service Pay Commission to separate the judiciary from the control of the executive.

On an extensive examination of constitutional provisions relating to subordinate courts (Articles 114-116A) and services of Bangladesh (Articles 133-136), the Appellate Division held that

"Judicial service is fundamentally and structurally distinct and separate service from the civil executive and administrative services of the Republic with which the judicial service cannot be placed on par on any account and that it cannot be amalgamated, abolished, replaced, mixed up and tied together withthe civil executive and administrative services."

\subsection{Implementation of the Judgment: Finally Separation of Judiciary from Executive}

Since the judgment was pronounced by the Appellate Division in 1999, the successive governments took 23 adjournments to implement the judgment on various pleas up to February, 2006. During these 7 years, the government took very slow steps towards the way of separation of judiciary.

The last Caretaker Government (of 2006-2008) from the very beginning adopted a positive and firm outlook with a determination to separate the judi- 
ciary from the executive based on the constitutional directive principles and Appellate Division's judgment in the Masdar Hossain's Case. Accordingly 4 service rules namely

1) Bangladesh Judicial Service Commission Rules, 2007,

2) Bangladesh Judicial Service (Pay Commission) Rules 2007,

3) Bangladesh Judicial Service Commission (Construction of Service, Appointments in and Suspension, Removal \& Dismissal from the Service) Rules, 2007; and

4) Bangladesh Judicial Service (Posting, Promotion, Grant of Leave, Control, Discipline and other Condition of Service) Rules, 2007 have been enacted and changes were bought in the existing Code of Criminal Procedure 1898 by Ordinance No II and No. IV of 2007.

This is considered to be a major change paving the way for dispensation of Criminal Justice at the level of magistracy by the officers belonging to Bangladesh Judicial Service and thereby removing all impediments in the separation of Judiciary from the executive control. Finally the historic journey of the judiciary separated from the executive started functioning from 01, November 2007.

From the above, it is convincing that after a long period of implementing article 22 as a fundamental principle of state policy, it was ultimately the Supreme Court which gave directions in the Masdar Hossain judgment for effecting separation and the process of implementation finally done in 2007. As a result Bangladesh got independent judiciary from other organs of the government. But in what extent this implementation has been succeeded is a question of fact.

\section{Judicial Independence in Bangladesh}

Separation of judiciary as well as judicial independence in Bangladesh has come into force at a practical sense through the decision of the Masdar Hossain case [2] as discussed at previous chapter. Now it is the question how far the judicial independence is ensured in our country and which is the procedure. To seek the answer it is indispensable to clear some points about the judicial independence such as the inevitable principles, some conditions as well as the status of judicial independence in our country etc. This part of the paper will attempt to focus on these issues.

\subsection{Principles of Judicial Independence}

The concept of judicial independence includes four basic principles, which have been suggested and recognized through international efforts in this field [6]. The following are the elaborated version of these four principles of judicial independence.

\subsubsection{Personal Independence}

Personal independence means that judges are not dependent on government in any way in which it might influence them in reaching decisions, in particular cases. Personal independence signifies that the tenure of judges and the terms 
and conditions of their service are "adequately secured so as to ensure that individual judges are not subject to executive controp" [7].

Therefore, to keep the administration of justice in a fair and impartial platform, a judge should be "placed in a position where he/she has nothing to be defeated by doing what is right and little to gain by doing what is wrong" [8]. This position can be guaranteed by ensuring the individual independence of a judge.

\subsubsection{Substantive Independence}

Substantive independence refers to the functional or decisional independence of judges to arrive at their decisions without submitting to any inside or outside pressure. The substantive aspect of the duties of a judge is the actual decision-making role. It is connected with the determination of the finding of fact and the application of the relevant legal norms to the facts of the case. Therefore, it ensures the impartiality of judges and their capacity to make judicial decisions on the merit of cases, without any fear or favor [9]. In determining the minimum standards of judicial independence the International Bar Association suggested in 1982 that in the discharge of his judicial function a judge is subject to nothing but the law and the commands of his ethics [7].

\subsubsection{Internal Independence}

Internal independence means independence of judges from their judicial superiors and colleagues. It refers to, in other words, independence of a judge or a judicial officer from any kind of order, indication or pressure from his judicial superiors and colleagues in deciding cases.

The independence of individual judges may be undermined not only by the outside sources of interference but also by fellow judges, particularly by senior judges using their administrative power and control [10]. This means that threat to internal independence may come from the superior courts or judges. In addition, internal independence covers the process of pronouncing judgment that is the actual decision-making process.

\subsubsection{Collective Independence}

Collective independence means institutional independence, which is connected with responsibility for the effective operation of the judiciary as an organ of government. In its easiest form, judiciary as an institute must be free from interferences of the executive or the legislature. Financial autonomy of the judiciary is also related to this concept of collective or institutional independence. A judge may not be able to exercise judicial function independently unless he or she is a part of an institution with authority over those human and physical resources incidental to performing judicial functions [11]. So, collective or institutional judicial independence is necessary to ensure the individual independence of judges.

Of these four types of independence of judge the substantive independence is the most important because it is the inner strength of the judges that provides the steering-force for them to maintain their impartiality in discharging judicial functions [12]. 


\subsubsection{Conditions of Judicial Independence}

The judiciary could not perform its solemn duties unless its independence is guaranteed and protected. It can be said that "Independence of the judiciary lends prestige to the office of a judge and inspires confidence in the general public" [13]. The main categories under the terms are discussed are

- Appointment of judges;

- Tenure of the judges;

- Discipline of judges;

- Adequate remuneration and privileges;

- Institutional independence of the judiciary.

\subsubsection{Appointment of Judges}

The basic principle of judicial independence requires that in administering justice judges should remain free from all kinds of direct or indirect interferences or influences. However, without impartial and fair selection and appointment of judges fair judgment is impossible. Therefore, appointment of judges is one of the basic requirements of independence of judiciary. In Bangladesh in terms of the eligibility criteria for appointment, judges of both the Supreme Court and subordinate courts will be appointed under provision of the constitution. Article 95(1) of the Constitution provides that "the chief justice shall be appointed by the President, and the other judges shall be appointed by the President after consultation with the chief justice".

\subsubsection{Tenure of Judges}

For the independence of judiciary security of tenure of judges is another important element. In the case of Walter Valente vs. Her Majesty the Queen, [14] it was cited that

"Security of tenure because of the importance traditionally attached to it is the essential conditions of judicial independence. The essentials of such security are that a Judge be removed only for cause, and that cause be subject to independent review and determination by a process at which the Judge affected is afforded a full opportunity to be heard."

The tenure of judges is another fundamental aspect of judicial independence that is closely connected with judicial appointment. When a person is appointed as a judicial officer, the next essential question is whether the tenure of his/her office or job is adequately secure or not? If the tenure of judges depends upon the pleasure of the executive authority, judges do not become free from the panic of arbitrary removal. In this circumstance, judicial power might be exercised by judges with a view to satisfying the authority that has the power to terminate their service [15].

\subsubsection{Discipline of Judges}

Judicial independence is predicated on "good faith" decision-making. It was never intended to include "bad-faith" decision-making, where a judge knowingly 
and deliberately disregards the facts and law of a case. This is properly the subject of disciplinary review, irrespective of whether it is correctable on appeal. And egregious error is also misconduct, since its nature and/or magnitude presuppose that a judge acted willfully, or that he is incompetent [16]. In Bangladesh the Constitution lays down provisions for the discipline of Supreme Court judges. Under Article 96 of the Constitution judges are subject to removal for misconduct and incapacity (both mental and physical), however, there are no Constitution provisions for corruption and criminal Offence.

\subsubsection{Adequate Remuneration and Privileges}

In order to ensure the independence and impartiality of the judiciary it is essential, next to the permanency of office, to provide judges with adequate remuneration and privileges. Firstly the salaries, housing facilities allowance and other privileges are to be such that they can easily maintain a reasonable standard of life and they do not have to drink for corruption or bribery. Again if judges are ill paid, able person will not be attracted to this profession, for they will have no prestige in the society.

\subsubsection{Institutional Independence}

Institutional independence is known as collective independence of judges. This actually means independence of the judiciary as an institute. In the context of Bangladesh, though there is a strong provision in the Constitution as enumerated in Article 22 that the state shall ensure the separation of the judiciary from the executive organs of the state. However, until on 1 November 2007 it was not separated from the executive. In following section attempt has been made to explore the present state of separation of the judiciary from the executive and judicial independence in Bangladesh.

\subsection{Judicial Independence in the Constitution}

The independence of judiciary can be measured by the provisions as Constitution contains in the matter of selection and appointment of judges, security of tenure, remuneration and other privileges, irremoveability except on proved misbehavior or misconduct, independence in the exercise of judicial functions, the assurance of compliance with the judges' decisions and the meat and substance of power and jurisdiction that it confers upon the judiciary [17].

There are several provisions in the current Constitution that guarantees judicial independence. Article 7 provides that all powers in the Republic shall be effective only under and by authority of the constitution. The responsibility of seeing that no functionary of the state oversteps the limit of his power is a necessity, on the judiciary. Article 22 of the Constitution clearly states about the obligation of the government to ensure judicial independence.

Article 35(3) of the Constitution provides that "Every person accused of a criminal offence shall have a right to a speedy and public trial by an independent 
and impartial court or tribunal established by law." In other words, the said Article guarantees a fundamental right to every criminally accused person in Bangladesh (whether citizen or not) to have a "speedy and public trial" by not only an "independent judiciary but also an Impartial judiciary".

Article 94(4) asserts that: "Subject to the provisions of this Constitution, the Chief Justice and the other Judges shall be independent in the exercise of their judicial functions." Financial independence is an integral part of the concept of judicial independence.

Though these articles contain safeguards as to judicial independence, these had been, in true sense, implemented through the decision of Masdar Hossain case [2].

\subsection{Structure of the Judiciary}

Separation of judiciary from the executive and judicial independence appears to have become an endless process. The debate started in the late 18th century and continues even now. However, now it is important to understand the present structure of the judiciary to be able to understand where executive intrusions into the judiciary originate and how these affect the independence of individual judges. At a glance the judiciary of Bangladesh consists of two divisions, the Supreme Court and the subordinate courts (Figure 1).

\subsubsection{Supreme Court}

The highest court in Bangladesh, the Supreme Court is actually composed of two divisions

- The Appellate Division, and

- The High Court Division.

The functions of the two are distinct, and separate appointments of judges are made to each. The Chief Justice of the Supreme Court sits in the Appellate Division and is the Chief Justice of Bangladesh; there is no separate Chief Justice of the High Court Division. The president, sometimes in consultation with the Chief Justice appoints the judges of the Supreme Court. While some Chief Justices in the past have insisted on being consulted on these appointments, others were not so exacting, leading to "Political" appointments by the party in power [18].

\subsubsection{Subordinate Court}

The lower judiciary in Bangladesh also consists of two parts: first, there are District courts and Sessions courts. In the view of the land mark decisions in Masder Hossain case back in 1999, the caretaker Government headed by Dr. Fakhruddin Ahrned amended the Criminal Procedure Code, 1898 in November, 2007 and along with these changes the lower judiciary was .separated from the control of the executive. Although the term "Executive" Magistrate still exists in the $\mathrm{CrPC}$, they are no longer vested with any judicial functions; their functions arc administered in nature. 


\section{Court system in Bangladesh}

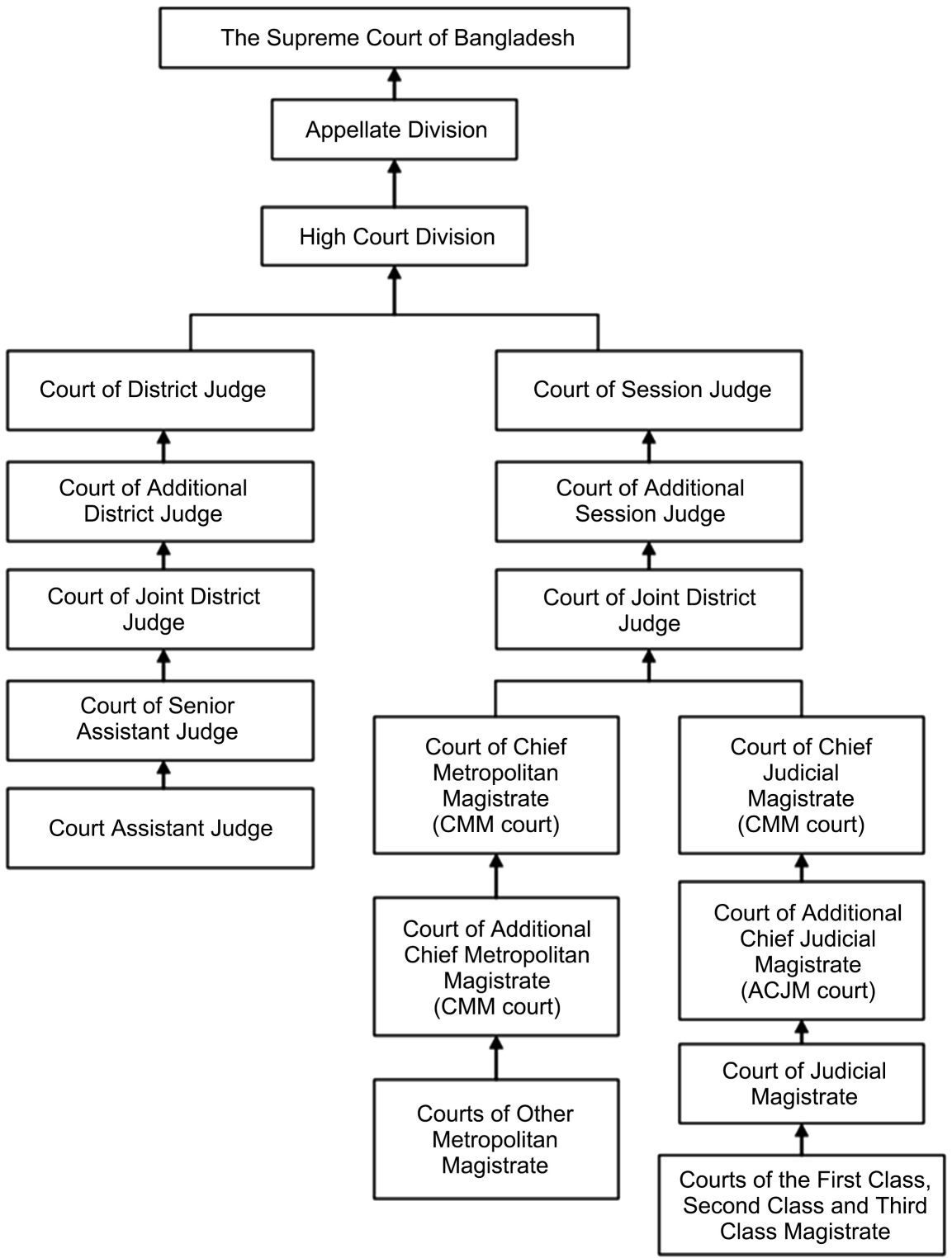

Figure 1. Hierarchy of courts in Bangladesh.

However, it is to be noted that by the Mobile Court Act, 2009 some judicial powers have been given to the Executive Magistrates. After November 1, 2007 the basic laws with regard to the separation of judiciary and newly constituted Judicial Service Commission are as follows:

To be mentioned here that with the enactment and enforcement of the Code of Criminal Procedure, 1898 (Amendment) Ordinance, 2007 and the other four rules as mentioned above, the structure of the lower courts in Bangladesh are as follows

\section{- Civil Courts}

- District Judges,

- Additional District Judges, 
- Joint District Judges,

- Senior Assistant Judges and

- Assistant Judges.

\section{- Criminal Courts}

○ Courts of Sessions;

1) Session Judges

2) Additional Session Judges

3) Joint Session Judges

- Magistrates

1) In metropolitan areas:

a) Chief Metropolitan magistrates

b) Additional Chief Metropolitan magistrates

c) Other Metropolitan magistrates

2) In other areas:

a) Chief Judicial Magistrates

b) Additional Chief Judicial Magistrates

c) Judicial Magistrates

d) Magistrates of

3) first class,

4) second class and

5) third class.

There are some special laws providing for the basis of some special courts or tribunals namely

- in relation to civil matters:

o the Administrative Tribunal,

○ the Environment Court,

o the Family Court,

○ the Juvenile Court,

○ the Labour Court and the Labour Appellate Tribunal,

- the Money Loans Court,

$\circ$ the Court of Settlement and the Taxes Appellate Tribunal.

- in relation to criminal cases:

- the Special Tribunal on Violence against Women and Children

○ the Special Tribunal for Speedy Trials etc.

\section{Judicial Independence in Bangladesh: How Far Ensured}

The Constitution of the People's Republic of Bangladesh came into force on December 16, 1972, the first anniversary of the country's independence. It contains fairly stringent safeguards for the independence of the judiciary, although the formal separation of powers has been ensured in 2007. Over the years, its safeguards for judicial independence, rather than being strengthened and consolidated, are still weak because of various controversies regarding balanced power, socio-political circumstances, lack of will of the government etc. 


\subsection{How Far Judicial Independence Is Implemented in Bangladesh}

The independence of the judiciary is the basic foundation of the constitution. On 7 August, 2008, the judge's bench consisting of Justice Abdur Rashid, justice Najmun Ara Sultana and justice Md. Ashtakul Islam pronounce the judgment of Idrisur Rahman vs. Bangladesh [19] case. Justice Abdur Rashid said, "Through the 12 directive principles of Masdar Hossain case [2] the Appellate Division confirmed a complete separation. The independence of the judiciary has been made separated from the executive and the legislative which has been come into force from November 1, 2007." But it can see that, the appointment of judges is regulated by the advice of prime-minister. In this context it has not been made clear the conflict with judicial independence [20]. Besides, the sixteen amendment of the constitution gives the power of impeachment of the Supreme Court judges to the members of parliament. Moreover, executive influence and interference on the judiciary are also practiced still now.

\subsection{Executive Interference in Lower Judiciary}

In a hierarchical judiciary, the higher courts usually control subordinate Courts to avoid digression from the higher standard of judicial behavior thus preventing damage to public confidence in the judiciary [21]. The HCD is authorized to administer, control, and supervise all subordinate courts [22]. All these constitutional provisions purport to establish an orderly system of judicial hierarchy in which subordinate courts remain accountable to the SC and not to the executive. The lower judiciary has an unequivocal mandate for its independence under Articles 109, 115, 116 and 116A of the Constitution. Yet the President appointed subordinate court judges and magistrates through the Law and/or Home Ministry without adhering to the constitutional safeguard of consultation with the SC.

The executive asserts absolute control over the lower judiciary, especially the magistracy, which enjoys little independence in performing judicial functions. The magistrates are an integral part of, and subordinate to, the executive. They serve only during the pleasure of the executive and have no choice but to carry out executive directives. Frequent government interference with lower court proceedings on political grounds and their use as a political weapon through undue favor in promotions arid transfers, adjournment of hearings, release of accused persons, and withdrawal of cases on political grounds are extensive. The national committee for reviewing and recommending the withdrawal of politically motivated' cases recommended 7,177 such cases since 2009 for withdrawal. It has selected 170, including 30 murder, cases for review without following the mandatory due procedure of referral from district committees headed by deputy commissioners [23]. Only competent trial courts, not the executive, should have the authority to order the adjournment of pending cases and the release of accused persons. Such executive interference subverts justice by undermining the provision for "public trial by an independent and impartial court" under Article 
35(3) of the Constitution and impairs the public image of the lower judiciary.

\section{Appointment of Public Prosecutor}

Bangladesh has a longstanding practice of appointing ruling party-affiliated lawyers as public prosecutors. It is alleged that, following the practices of the past, the current government has replaced the entire group of public prosecutors with members or genuine supporters of the governing party and has also made politically motivated appointments to the Office of the Attorney General.

\subsection{Executive Interference in Higher Judiciary}

Not only the lower judiciary, the higher judiciary i.e. Supreme Court (Appellate Division and High Court Division) is also still now under the influence of executive control. Executive manifested such control in many ways such as appointment of Justice, controlling Bar Council; Bar Association are the few examples. It is often said that now the higher judiciary is highly politicized and therefore independence is still yet to be achieved truly.

\subsubsection{Suppression in the Procedure of the Appointment}

The executive played enough roles in this regard, because it is the executive i.e. the president who appoints the justice (including Chief Justice) and we know that president does what is recommended by the Prime Minister. Although the president is not bound to consult with the prime minister with regard to the appointment of Chief Justice, such practice may hardly be found. Therefore, in appointing judges the rule of seniority is not often complied and there are many instances in this regard. Besides there are no clear guidelines for the appointment of judges which pave the way to exercise naked interference in the function of the Higher Judiciary. There has been controversy over appointment of the Chief Justices of Bangladesh as well. In the appointment of the CJ, the principle of seniority, as reflected in Articles 96 and 97 of the Constitution and in Bangladesh vs. Md. Idrisur Rahman, [24] was largely recognized. However, the principle has been repeatedly violated in recent years with four of the last six appointments seeing the senior-most judge of the Appellate Division being superseded. The appointment of Chief Justice A.B.M-Khairul Haque by the President in September 2010 was alleged to have involved the supersession of two more senior judges of the Appellate Division. Similar controversies arose in the appointment of the present Chief Justice of Bangladesh, Justice Muzammel Hossain on 18 May, 2011. In this appointment, Justice Shah Abu Nayeem Momihur Rahman was superseded (and then he resigned).

\subsubsection{Absence of Guideline for the Appointment}

The High Court judges are appointed as per article 95(2) 6f the Constitution. Again under Article 90 the president is empowered to appoint one or more qualified persons as additional judges for two years. But here the objectionable point is the proviso of the Article where it is said that the president can appoint 
such an additional judge as a regular judge or for a., further period. It is objectionable in the sense that the power-expectation among such additional judges to get regular judgeship may greatly hamper their discharging impartial justice.

\subsubsection{Post Retirement Appointment}

Under Article 99 a retired or removed judge may be appointed by the president in judicial or quasi judicial offices and may also be appointed as a Minister, Deputy Minister or President which are not regarded as profitable posts under Article 66(2). This provision is a great hindrance to the independence of judiciary in Bangladesh. As per the opinion of Ahmed J. who observed that, "opening up of opportunities for appointment after retirement will serve as a temptation and temper with his independence during the concluding period of his service [24]."

\subsection{Judicial Independence vs. Sixteenth Amendment}

Judicial independence means judiciary as an organ of the government independent from interference of other organs i.e. the executive arid the legislative. Our constitution is a safeguard of judicial independence in our country as its article 22 says that, "The state shall ensure the separation of the judiciary from the executive organs of the State." But despite of such provision it is a j matter of concern that judicial independence is threatened by some activities. One such threat is the sixteenth amendment of the constitution which has conferred the power to remove the judges of the Supreme Court (SC) on the members of parliament through the amendment of article 96.

On August 18, 2014, the Cabinet approved the proposal for amendment to the Constitution to pave the way for restoring Parliament's authority to impeach Supreme Court judges for misconduct or incapability. After that, on September 17, Parliament unanimously passed the "Constitution ( $16^{\text {th }}$ Amendment) Bill, 2014" without any opposition. According to the previous constitutional provision, the Supreme Judicial Council comprising the chief justice and two other senior most judges of the Appellate Division would investigate allegations of misconduct against any SC judge and make necessary recommendations to the President. The President would then take steps as per the suggestions. He could also impeach a judge for having physical and mental incapacity to properly perform the functions of his office. But now, the provision is, "a Judge shall not be removed from his office except by an order of the President passed pursuant to a resolution of Parliament supported by a majority of not less than two-thirds of the total number of members of Parliament, on the ground of proved misbehaviour or incapacity [25]." However, the modalities of investigation arid proof regarding the moral disqualification orinability will be controlled by laws of Parliament [26].

In the case Idrisur Rahman vs. Bangladesh, [27] JusticeAbdur Rashid refers three "cardinal aspects" to confirm the judicial independence. These are

But now, It's indeed a fateful moment in the nation's history since the basis of 
principles of separation of powers and the checks and balances between the three organs of the state on which the entire democratic system of governance stands have thus been negated in one fell jump. And with this enactment, the government has effectively bound the judiciary by leaving it to the mercy of the ruling party that can exercise its brute majority in parliament to unseat a judge [28]. Many jurists and Opposition political parties fear that the independence of the judiciary will be in jeopardy following the latest amendment. The Supreme Court Bar Association (SCBA) President, Advocate Khandker Mahbub Hossain, in a press briefing at the Supreme Court auditorium held by SCBA on 18 September, 2014 said that

"The government has brought the amendment to undermine the independence of the judiciary. People will not accept the bill and the government will have to face public ire in future," [29]

The judiciary is independent, and it cannot be controlled by any organ of the state. Moreover, to become a parliamentarian, no specific academic qualification is determined in the constitution, but a lawyer or a lower court judge needs at least 10 years of job experience to become an SC judge. Therefore, a lawmaker should not be empowered to determine the fate of an SC judge, who is academically more qualified than him.

In defence, the government has cited the existing provisions for impeachment of higher levels courts' judges in some democratic countries like India, Canada, Australia and USA-where the parliaments enjoy the powers to impeach the judges. But the government clearly avoided saying anything about the mechanism for the judicial appointments in those countries. Let's see what is scenario on other countries:

The Indian parliament has recently amended the constitution to build mechanism for better judicial appointments. The amendment made provision for the setting up of a National Judicial Appointments Commission (NJAC) which will appoint and transfer judges to the Supreme Courts and the 24 High Courts. Chief Justice of India will head the NJAC. Besides the chief justice, the judiciary world be represented by two senior judges of the Supreme Court [30].

In UK parliament, to maintain and strengthen judicial independence, the Judicial Appointment Commission was set up in 2006 with the responsibility for selecting candidates for judicial office in a transparent and accountable process [30].

So, the sixteen amendment of the constitution is behind the theory if separation of power. It gives exclusive power to the members of parliament over the judges of the SC, To say in other languages, it is a threat to the establishment of judicial in dependence. Moreover, it can be used by the leading party in a political interest.

\section{Safeguards of Judicial Independence}

The primary talk on the independence of the judiciary is based on the doctrine 
of separation of powers. As to this theory the judiciary should remain separated and independent from the executive and the legislature branches of the government. In November 2007, the subordinate judiciary in Bangladesh was formally separated from the executive by bringing in force the main findings of the case of Masdar Hossain [2]. But it should be noticed that despite the judiciary is separated from the other organ, is the proper independence has been confirmed in our country, whether only separation power can ensure judicial independence, this chapter will focus to answer these asking.

\subsection{Whether Only Separation of Judiciary Is Enough to Ensure Judicial Independence}

By ensuring judicial independence from the executive organ of the government, we are, no doubt, in a position of installing a better democratic system in our society, but there still remains a grey area as to how efficient this system would work if the players and the operators of this system are not motivated enough to make it work. Therefore, if "separation of judiciary" from the executive organ is the first step, let securing "impartial judiciary" be the next one to ensure the actual independence of judiciary. There are also some other factors also which play important role in judicial independence.

Moreover, Independence of the judiciary is undisputedly said to be the basic requisite for ensuring a free and fair society under the rule of law. While the judiciary as an institution should be independent in terms of finance and administration, the judges, should be independent and free from all external factors in order to exercise the judiciary's functions in an unbiased manner.

\subsection{In Which Way Judicial Independence Can Be Ensured}

In the modern constitutional State, the principle of an independent Judiciary has its origin in the theory of separation of powers. This constitutes a system of mutual checks and balances aimed at preventing abuses of power to the detriment of a free society.

In this context, the Institute of Governance Studies (IGS), by way of a Policy Note, aims to provide a number of policy recommendations, which could further strengthen the independence of the judiciary.

This Policy Note focuses on four issues:

1) Independence

2) Accountability

3) Efficiency

4) Effectiveness

Judicial independence does, however, mean that judges must be free to exercise their judicial powers without interference from litigants, the State, the media or powerful individuals or entities, such as large companies. Besides, Judges must operate with impartiality, integrity and propriety. From these aspects we can determine some factors which should be kept with the place of separation of 
judiciary.

\section{Judicial Impartiality}

It is not enough for the judiciary, as an institution, to be independent-individual judges must be seen to be objective and impartial. They must treat lawyers, clients and witnesses with respect and must refrain from comments that suggest they have made up their minds in advance. Outside the courtroom, judges do not socialize or associate with lawyers or other persons connected with the cases they hear, or they may be accused of favoritism [31]. Judges typically declare a conflict and withdraw from a case that involves relatives or friends. The same is true if the case involves a former client, a member of the judge's former law firm, law partners or a former business associate, at least until a year or two has passed since the judge was appointed and those ties were severed.

Walter Valente held that "the concepts of independence' and 'impartiality', although obviously related, are separate distinct values or requirements. But both of them are essential for Judicial independence ..."

\section{Suggestions and Conclusions}

The primary condition on the independence of the judiciary is based on the doctrine of separation of powers, which holds that the judiciary should remain separated and independent from the executive and the legislature branches of the government. The concept of independence of judiciary also includes numerous aspects like: appointment, posting, promotion, tenure, discipline and other forms of informal matters of judges. This paper has sought to identitfy how far this term is evaluated at the context of our country.

Judiciary forms the basic element of the statehood shaped by deliberate policies to establish social justice and equality of all citizens. It protects the weak from the powerful; the minority from the majority; the poor from the rich; even the citizens from excesses of government. Separation of Judiciary is the precondition to ensure the judicial independence. Although separation of judiciary has confirmed in 2007 in Bangladesh, it has not attained the hope of people due to theoretical problems in some other factors.

Executive encroachments on judicial independence regarding the judges' day to day decision making are a subject of widespread and increasing public concern. Therefore, the judicial norms and practice have been derogating for years in Bangladesh. To ensure the proper independence of judiciary, some measures may be taken besides the separation of judiciary.

\section{Recommending Measures}

To meet the needs of the actual and proper independence of judiciary, the following measures may be taken:

1) An impartial judiciary, an independent legal profession, an impartial prosecution and the integrity of the judicial system are prerequisites to ensure the judicial independence. 
2) Judges should perform their functions fairly, consistently and expeditiously.

3) Though the judiciary is separated from executive, undue influence from executive is a common barrier in delivering judgment by judges. Therefore it is crying necessity to have more safe protection for judicial officers as well as Judiciary should not be dictated by any undue influence from executive organ.

4) It is essential to ensure the professional qualifications of judges, prosecutors, lawyers and court officials.

5) The term of office of judges, their independence, security, adequate remuneration, and conditions of service, pensions and the age of retirement should be adequately secured by law.

6) A Judge's decision on appeal must be independent and impartial, uninfluenced by any outside pressure.

7) All the articles of constitution related to the independence of judiciary have to be implemented.

8) The Judicial procedure should be simple and judges should have effective power to override technicalities.

9) The Government may consider Amendment of the Constitution so as to restore the original Articles 115 and 116 of the Constitution providing for full control and discipline of the subordinate courts in the Supreme Court [32].

10) Judiciary must have autonomous financial source allocated by the government which will be adequate financial support to perform its functions properly.

In Bangladesh, separation of judiciary as well as judicial independence has come into light after a long pathway through the decision of Masdar Hossain case [2]. But the implementation of the gain is not still satisfactory. The study has been made on the facts that analyse and evaluate the terms. It also attempts to make a recommending step to overcome the barriers. But it is vital to say at the time of ending that only making provisions is not sufficient to ensure independence of judiciary unless the judges, legislators, executive and others show their interest to ensure it.

\section{Conflicts of Interest}

The authors declare no conflicts of interest regarding the publication of this paper.

\section{References}

[1] Art 22, the Constitution of the People's Republic of Bangladesh, Done at Dhaka, 4 November 1972, in Force 16 December 1972. http://bdlaws.minlaw.gov.bd/act-details-367.html

[2] Judgment (1999) Secretary, Ministry of Finance vs. Masdar Hossain, 52 Dhaka Law Report (AD), p. 82.

https://shamimsufi.files.wordpress.com/2013/05/secretary-ministry-of-finance-vsmd-masdar-hossain-and-others-52-dlr-ad-82.pdf

[3] Constitution of the People's Republic of Bangladesh (1972) Done at Dhaka. 
[4] Islam, M. (2006) Constitutional Law of Bangladesh. 2nd Edition, Mullick Brothers, Reprint, 65.

[5] Hossain, M.M. (2020) Separation of Judiciary in Bangladesh-Constitutional Mandates and Masdar Hossain Case's Directions: A Post Separation Evaluation. International Journal for Court Administration, 11, 4. https://doi.org/10.36745/ijca.310

[6] Ershadul Bari, M. (1993) Importance of an Independent Judiciary in a Democratic State. The Dhaka University Studies, Part F, 4, 1-11.

https://law.du.ac.bd/en/wp-content/uploads/2017/09/Volume.-IV-No.1-June-1993. pdf

[7] Akkas, S.A. (2004) Independence and Accountability of Judiciary-A Critical Review. Centre for Rights and Governance (CRIG), Dhaka, 22.

[8] Dawson, R.M. (1954) The Government of Canada. The University of Toronto Press, Toronto, 486.

[9] Geyh, G.C. and Tassel, V.E.E. (1998) The Independence of the Judicial Brance in the New Republic. Chicago-Kent Law Review, 74, 31.

[10] Russell, P.M. (2001) Towards a General Theory of Judicial Independence. In: Russell, P. and O'Brien, D.M., Eds., Juridical Independence in the Age of Democracy: Critical Perspectives from Around the World, University Press of Virginia, London, 6.

[11] Millar, S.P. (1981) Judicial Administration in Canada. McGill-Queen's University Press, Kingston, 54. https://doi.org/10.2307/j.ctt1w1vn82

[12] Halim, M.A. (1998) Constitution Constitutional Law and Polities: Bangladesh Perspective. Rico Printers, Dhaka, 342.

[13] Rohson, W.A. (1951) Justice and Administrative Law.

[14] Walter Valente vs. Her Majesty the Queen (1985) 2 RCS 673. https://scc-csc.lexum.com/scc-csc/scc-csc/en/item/108/index.do

[15] Fricdland, M.L. (1995) A Place Apart: Judicial Independence and Accountability in Canada. Canadian Judicial Council, Toronto, 2.

[16] Sarrower, E.R. (2008) On Judicial Misconduct and Discipline-Without Merit: The Empty Promise of Judicial Discipline. Massachusetts School of Law, 4, 90. http://www.tulanelink.com/tulanelink/sassower 01a.htm

[17] Kamal, J.M. (1994) Bangladesh Constitution: Trends and Issues. University of Dhaka, Dhaka, 27.

[18] Karim, M.A. (2014) Separation of Judiciary in Bangladesh. International Journal of Human Rights and Constitutional Studies, 2.

https://www.inderscienceonline.com/doi/pdf/10.1504/IJHRCS.2014.067882

[19] ldrisur Rahman vs. Bangladesh (2008) 60 Dhaka Law Report, 714.

[20] Judgement (1993) Bangladesh vs. Aftabuddin, 48 Dhaka Law Report.

[21] HussainaraKhatoon vs. State of Bihar (1979) Cr LJ. 1045. https://indiankanoon.org/doc/1373215/

[22] Article 109, the Constitution of the People's Republic of Bangladesh, Done at Dhaka, 4 November 1972, in Force 16 December 1972.

http://bdlaws.minlaw.gov.bd/act-details-367.html

[23] Islam, M.R. (2013) 2013 Independence of the Judiciary-The Masdar Case. Daily Star, 6 August.

https://www.thedailystar.net/independence-of-the-judiciary-the-masdar-case-14760

[24] Bangladesh v. Idrisur Rahman (2010) 15 Bangladesh Law Chronicles (AD), p. 49. 
[25] Cited by Abdul Halim in Constitution, Constitutional Law and Politics: Bangladesh Perspective (1998), 308.

[26] Article 96(2) of the Constitution of the People's Republic of Bangladesh Substituted by the Constitution (Sixteen Amendment) Act, 2014 (Act. No xiii of 2014).

[27] Article 96(3) of the Constitution of the People's Republic of Bangladesh Substituted by the Constitution (Sixteen Amendment) Act. 2014 (Act. No xiii of 2014).

[28] The Daily Star (2014) 16th Amendment to the Constitution: Will It Be the Last Nail in the Independent Judiciary's Coffin? 19 September.

https://www.thedailystar.net/16th-amendment-to-the-constitution-42292

[29] Rahman, M.S. (2014) 16th Amendment Draws SCBA's Flak. The Daily Independent, 19 September 2014.

[30] Liton, S. (2014) Judges' Impeachment by JS. The Daily Star, 6 September 2014.

[31] Hossain Mollah, A. (2012) Independence of Judiciary in Bangladesh: An Overview. International Journal of Law and Management, 54, 61-77. https://doi.org/10.1108/17542431211189605

[32] Sushma Suri vs. Govt. of National Capital Territory of Delhi (1999) 1 SCC 330; High Court of Rajasthan vs. Ramesh Chand Paliwal, AIR 1998 SC 1079.

https://completejusticepodcast.s3.ap-south-1.amazonaws.com/Mahendra+Singh+-+ The+Independence+of+the+Judiciary+-+Separation+from +the+Executive.pdf 